\title{
Pengaruh Lokasi Terhadap Keputusan Berkunjung Wisatawan (Studi Kasus Objek Wisata Hutan Pinus Loji Lereng Kelud)
}

\author{
Effect of Location on Tourist Decisions \\ (Case Study of Tourist Attraction Hutan Pinus Loji Lereng Kelud)
}

\author{
Novita Putri Diantanti ${ }^{1}$, Isya Asrori ${ }^{2}$ \\ ${ }^{1}$ Fakultas Ilmu Sosial dan Politik, Universitas Islam Balitar \\ Jl. Majapahit No.2-4 Blitar, Indonesia \\ ${ }^{2}$ Fakultas Ilmu Sosial dan Politik, Universitas Islam Balitar \\ Jl. Majapahit No.2-4 Blitar, Indonesia \\ E-mail: novita.putrid@gmail.com
}

\begin{abstract}
ABSTRAK
Yang menjadi permasalahan utama dari studi kasus yang akan diteliti adalah apakah ada pengaruhnya lokasi terhadap keputusan untuk datang ke wisata hutan pinus loji lereng kelud. Sedangkan yang menjadi tujuan penelitian adalah agar dapat diketahui pengaruhnya lokasi terhadap keputusan berkunjung di Wisata Hutan Pinus Loji Lereng Kelud. Untuk memperoleh dan agar dapat mengetahui hasilnya maka peneliti menggunakan metode deskriptif, uji statistik deskriptif, uji instrumen yang meliputi pengujian validitas dan uji reliabilitas. Sedangkan untuk uji asumsi klasik meliputi pengujian normalitas, uji autokorelasi, uji heteroskedastisitas, dan uji t. Pelaksanaan penelitian dimulai dari tanggal 01 april dan berakhir tanggal 30 april 2019 di wisata hutan pinus loji lereng kelud Desa Tulungrejo, Kec. Gandusari, Kab Blitar. Setelah dilakukan pembahsan dihasilkan bahwa nilai t hitung 2,204 dan t tabel adalah 1,66 dihitung dari nilai sig two-tailed adalah 5\%(0,05) maka dapat diambil kesimpulan nilai T hitung mendapatkan hasil lebih besar dari nilai $\mathrm{T}$ tabel, sehingga dapat dikatakan bahwasannya lokasi memiliki pengaruh terhadap keputusan berkunjung wisatwan. Atau pada nilai $\mathrm{Ha}$ diterima karena $\mathrm{T}$ hitung lebih besar dari nilai $\mathrm{T}$ tabel dan Ho ditolak karena nilai $\mathrm{T}$ tabel tidak lebih besar dari nilai $\mathrm{T}$ hitung. Kesimpulan pada penelitian ini adalah bahwa lokasi memiliki pengaruh terhadap keputusan mengunjungi objek wisata. Oleh karena bagi pengelola diharapkan dan memberikan konsep lagi terhadap wisata trsebut agar lebih berkembang.
\end{abstract}

Kata Kunci : Lokasi, Keputusan Berkunjung, Wisatawan

\section{ABSTRACT}

The main problem of the case study to be investigated is whether there is an effect on the location of the decision to come to a tour of the kelud slopes loji pine forest. Meanwhile, the research objective is to know the effect of location on the decision to visit the Kelud Loji Slope Pine Forest Tourism. To obtain and in order to know the results, the researchers used descriptive methods, descriptive statistical tests, test instruments which included validity testing and reliability testing. Meanwhile, the classical assumption test includes normality test, autocorrelation test, heteroscedasticity test, and t test. The research was carried 
out starting from April 1 and ending on April 30, 2019 in the pine forest tourism slopes of the kelud village of Tulungrejo, Kec. Gandusari, Blitar Regency. After discussion, the result shows that the $t$ value is 2.204 and the table is 1.66 calculated from the two-tailed sig value is 5\% (0.05), it can be concluded that the calculated $T$ value is greater than the $T$ table value, so it can be said that the location has an influence on the decision to visit tourists. Or the Ha value is accepted because T count is greater than the T table value and Ho is rejected because the T table value is not greater than the T count value. The conclusion in this study is that the location has an influence on the decision to visit a tourist attraction. Therefore, it is hoped that the manager will give more concepts to the tourism so that it is more developed.

Keywords : Locations, Visiting Decisions, Travelers

\section{PENDAHULUAN}

Tempat wisata saat ini sudah menjadi kebutuhan bagi manusia. Meski menjadi suatu kebutuhan sekunder bagi manusia, akan tetapi berwisata dapat menghilangkan kejenuhan dan penat dalam menghadapi rutunitas harian seperti perkerjaan dan kepadatan kota yang memerlukan kontrasi tinggi sehingga dapat membuat jenuh. Dalam UU RI Nomor 10 Tahun 2009 terkait pariwisata menjelaskan bahwasannya wisata merupakan aktivitas perjalanan yang dilaksanakan oleh seseorang ataupun kelompok yang berkunjung ke tempat yang dituju dengan maksud untuk rekreasi, mengembangkan pribadi, ataupun belajar mengenai keunikan serta daya tarik tempat wisata yang didatangi pada waktu yang sementara. Objek wisata merupakan sebuah produk yang diperlukan bagi seorang wisatawan. Dalam upaya meningkatkan sektor pariwisata agar tetap berlangsung maka memerlukan sebuah strategi. Dalam hal ini strategi juga sangat berperan penting untuk meningkatkan produk suatu objek wisata, hal ini karena dengan adanya strategi yang bagus terhadap suatu objek wisata secara tidak langsung dapat meningkatkan kunjungan wisatawan.

Pada dasarnya pariwisata berhubungan erat dengan pemasaran, untuk pengelola sebuah objek wisata maupun pihak terkait juga melakukan kegiatan pemasaran. Kegiatatn pemasaran terdapat 4 dasar antara lain : produk, tempat, promosi, dan lokasi (Kotler, 2005). Hal ini dikarenakan memasarkan produk adalah suatu sistem yang efektif untuk bisnis yang dibagun guna melakukan perencanaan, menetapkan harga, mepromosikan dan mendistribusikan produk, jasa dan ide-ide yang dapat terciptanya kepuasan dari apa yang diinginkan pasar 
sebagai upaya agar tercapainya tujuan organisasional (Tjiptono, 2005).

Dalam pariwisata guna menujang kedatangan pengunjung juga diperlukannya lokasi yang strategis mudah dijangkau. Menurut Manullang (1990) mengatakan memilih lokasi atau tempat diperlukan penilaian yang tepat sehingga pelanggan bisa menentukan keputusan dalam melakukan pembelian, hal tersebut dituntut untuk terjadi kesesuaian dengan kriteria seperti pusat kegiatan ekonomi yakni kantor, bank, toko, hiburan dan lain-lainya. Pada dasarnya wisatwan dalam menuju objek wisata memerlukan akses yang mudah, dan wisatawan juga memerlukan kenyamanan lokasi serta keindahan lokasi, hal tersebut dapat menjadikan salah satu minat wisatawan dalam berkunjung.

Dengan melihat potensi banyaknya wisata alam khususnya di daerah Kabupaten Blitar, serta meningkatkan potensi wisata tersebut agar banyak aktifitas berkunjung oleh wisatawan. Melihat dari pemaparan sebelumnya, maka peneliti tertarik meneliti tetantang pengaruhnya lokasi terhadap keputusan berkunjung wisatawan dengan mengambil kasus di objek wisata Hutan Pinus Loji Lereng Kelud.

\section{METODE PENELITIAN}

Kegiatan penelitian dilaksanakan di Objek Wisata Hutan Pinus Loji Lereng Kelud Desa Tulungrejo, Kecamatan Gandusari, Kabupaten Blitar. Sugiyono (2017) menyebutkan bahwa populasi dapat dikatakan sebagai wilayah generalisasi meliputi objek ataupun subjek yang terdapat kualitas serta sifat tersendiri untuk digunakan peneliti guna dipelajari dan selanjutnya mengambil kesimpulan berdasarkan fenomena yang ada. Pada riset ini populasinya yaitu para pengunjung atau wisatawan pada Objek Wisata Hutan Pinus Loji Lereng Kelud. Sedangankan sampel merupakan komponen dari sejumlah karekteristik yang terdapat pada populasi (Sugiyono, 2017). Dalam nenetukan jumlah sampel yang ada pada suatu populasi maka peneliti menggunakan teknik penghitungan slovin. Dengan hasil wawancara kedatangan pengunjung sekitarv 400 pengunjung per bulan. Dan peneliti menetapkan 400 pengunjung per bulan sebagai populasi.

$$
n=\frac{N}{1+N e^{2}}
$$


Keterangan :

$$
\begin{aligned}
& \mathrm{n}=\text { Menunjukkan jumlah dari sampel } \\
& \mathrm{N} \quad=\text { Menunjukkan populasi } \\
& \text { e } \quad=\text { Tingkat dari kebermaknaan } 10 \% \text { atau } 5 \% \\
& n=\frac{N}{1+N e^{2}} \\
& =\frac{400}{1+400(10 \%)^{2}} \\
& =\frac{400}{1+800(0,1)^{2}} \\
& =\frac{400}{1+400(0,01)} \\
& =\frac{400}{1+4} \\
& =\frac{400}{5} \\
& =80
\end{aligned}
$$

Dari perhitungan tersebut, maka yang digunakan sebagai sampel yaitu sebanyak 86 orang.

Untuk teknik mengambil sampel digunakan pendekatan Sampling Insidental, dimana dalam teknik ini untuk menentukan sampel didasarkan pada kebutuhan peneliti, yakni siapa-siapa yang secara tidak sengaja (insidental) dijumpai oleh peneliti dapat dipergunakan untuk sampel, apabila diniliai orang tersebut sesuai untuk digunakan menjadi sumber data (Sugiyono, 2017). Selain itu, peneliti juga menetukan kriteria yang digunaka untuk dijadikan sampel yaitu orang ataupun wisatwan yang pernah mengunjungi Objek Wisata Hutan Pinus Loji Lereng Kelud.

Variabel penelitian adalah sebuah objek yang dijadikan penelitian, dan diamati pada dalam aktivitas penelitian, yang memperlihatkan variasi, baik melalui pendekatan kuantitatif ataupun kualitatif (Arikunto, 2006). Variabel yang digunakan terdiri dari variabel bebas atau independen dan variable terikat atau dependen. Untuk variabel bebas yang digunakan yaitu promosi dan lokasi, serta 
untuk variabel terikat adalah keputusan. Terdapat 2 variabel didalam riset ini, yaitu:

Variabel X : Lokasi

Variabel Y : Keputusan Berkunjung

\section{HASIL DAN PEMBAHASAN}

\section{Uji Validitas}

Uji ini bertujuan untuk pengukuran dari kevalidan ataupun sah tidaknya kuesioner yang digunakan. Sebuah angket atau kuesioner dinyatakan valid apabila butir pertanyaannya dapat mampu agar terungkap sesuatu yang akan diukur dengan kuesioner. Salah satu teknik dalam menguji validitas yaitu menggunakan Pearson Correlation dengan melihat hasil nilai dari Sig. (2-tailed) $0,000<\alpha 0,01$ (Nugroho, 2005). Oleh karena itu maka peneliti menyajikan uji validitas untuk variabel lokasi yang tersaji di Tabel 1 .

Tabel 1. Hasil Pengjuian Validitas Variabel X

\begin{tabular}{|c|c|c|}
\hline Item Pertanyaan & Sig & Keputusan \\
\hline X1 & 0,00 & Valid \\
\hline X2 & 0,00 & Valid \\
\hline X3 & 0,00 & Valid \\
\hline X4 & 0,00 & Valid \\
\hline X5 & 0,00 & Valid \\
\hline
\end{tabular}

Dari tabel 1 dapat terlihat bahwasannya hasil Sig (2-tailed) semua item pada variabel lokasi $<0,01$ hal ini bisa dikatakan bahwasanya dalam pengujian uji validitas tidak memiliki masalah atau dapat dikatakan data dalam variabel lokasi valid hal dapat dijadikan sebagai pengambilan sebuah data.

Tabel 2. Hasil Uji Validitas Variabel Y

\begin{tabular}{|c|c|c|}
\hline Kode pertanyaan & Sig & Keputusan \\
\hline Y1 & 0,00 & Valid \\
\hline Y2 & 0,00 & Valid \\
\hline Y3 & 0,00 & Valid \\
\hline Y4 & 0,00 & Valid \\
\hline Y5 & 0,00 & Valid \\
\hline
\end{tabular}

Pada hasil yang tersaji pada tabel 2 diketahui bahwasannya uji validitas memperlihatkan nilai Sig (2-tailed) semua item pada variabel keputusan 
berkunjung $<0,01$ hal ini bisa dikatakan bahwasanya dalam pengujian uji validitas tidak memiliki masalah atau dapat dikatakan data dalam variabel keputusan berkunjung valid, maka dalam hal ini dapat dijadikan sebagai pengambilan sebuah data.

\section{Uji Realibilitas}

Menguji reliabilitas digunakan agar diketahui nilai dari tingkat kesahihan data agar dapat menghasilkan data yang tepat dan sesuai dengan fakta yang ada serta bisa dipergunakan berulangkali di waktu yang berbeda (Siregar, 2017). Uji realibilitas digunakan pendekatan Cronbach Alpha ( $\alpha$ ) yakni apabila $\alpha>0,60$ maka dinyatakan reliable. Dalam penghitungan pada uji reliabilitas peneliti menyebar kuisioner kepada 86 responden dengan hasil uji tersaji pada Tabel 3.

Tabel 3. Hasil Uji Reliabilitas

\begin{tabular}{|c|c|c|}
\hline Variable & Cronbach Alpha & Explanation \\
\hline Lokasi & 0,749 & Reliable \\
\hline Keputusan Berkunjung & 0,646 & Reliable \\
\hline
\end{tabular}

Pada tabel 3 terkait hasil pengujian realibilitas menunjukan bahwasannya seluruh variabel yang dipergunakan pada penelitian menghaslikan Cronbach Alpha > 0,60 maka dapat dinyatakan bahwa pengukuran dari semua variabel dalam penelitan adalah reliable dan berarti intrumen dalam pengujian variabel tersebut dapat digunakan dalam sebuah penelitian.

\section{Uji Normalitas}

Menguji normalitas memiliki tujuan agar dapat diketahui apakah data sampel yang dipakai bersumber dari populasi yang memiliki distribusi normal ataupun tidak (Zulfikar dan Budiantara, 2014). Untuk menguji normalitas dapat menggunakan beberapa cara, salah satunya menggunakan Kolmogorov-Smirnov. Normal atau tidaknya data juga bisa melihatnya dari pengujian normalitas Kolmogorov-Smirnof yang didasarkan pada hasil dari unstandardized residual (e). Analisis datanya menggunakan software SPSS. Sedangkan dasar dari pengambilan keputusan didasarkan pada probabilitas. Apabila probabilitas $>0,05$ sehingga dapat dinyatakan data yang digunakan terlah terdistribusi normal (Ghozali, 2006).

Tabel 4. Pengujian Normalitas 


\begin{tabular}{|ll|r|}
\hline & & \multicolumn{1}{|c|}{ Unstandardized } \\
& Residual \\
\hline $\mathrm{N}$ & & 86 \\
Normal Parameters, & Mean & .0000000 \\
& Std. Deviation & 2.00179405 \\
Most Extreme Differences & Absolute & .080 \\
& Positive & .056 \\
& Negative & -.080 \\
Kolmogorov-Smirnov Z & & .744 \\
Asymp. Sig. (2-tailed) & .637 \\
\hline
\end{tabular}

Berdasarkan hasil yang tersaji dalam tabel 4 yang merupakan output dari software SPSS dengan teknik Kolmogorov-Smirnov, maka dapat disimpulkan bahwa uji normalitas yang telah dilakukan adalah berdistribusi normal. Hal ini karena dalam pengujian melalui Program SPSS yang telah dilakukan peneliti hasil Asymp Sig.(2-Tailed) dengan nilai 0,637. Nilai ini lebih besar dari nilai klasifikasi standar sebesar 0,05 .

\section{Uji Hekteroskedastisitas}

Pengujian heteroskedastisitas dilakukan dengan teknik uji Spearman. Menurut Purnomo (2017), uji Spearman menggunakan teknik pengujian terhadap koefisien korelasi Spearman's rho yakni melakukan korelasi independent variable dengan residualnya. Kondisi heteroskedastisitas terjadi jika korelasinya diantara variabel independen dengan residual mendapatkan signifikansi kurang dari 0,05.

Tabel 5. Hasil Pengujian Heteroskedastisitas

\begin{tabular}{|c|c|c|c|c|}
\hline & & & LOKASI & $\begin{array}{c}\text { Unstandardized } \\
\text { Residual }\end{array}$ \\
\hline \multirow{6}{*}{$\begin{array}{l}\text { Spearman } \\
\text { 's rho }\end{array}$} & LOKASI & Correlation Coefficient & 1.000 & -.007 \\
\hline & & Siq. (2-tailed) & & .947 \\
\hline & & $\mathrm{N}$ & 86 & 86 \\
\hline & Unstandardized & Correlation Coefficient & -.007 & 1.000 \\
\hline & Residual & Sig. (2-tailed) & .947 & \\
\hline & & $\mathrm{N}$ & 86 & 86 \\
\hline
\end{tabular}

Berdasarkan pengujian uji heteroskedastisitas pada Tabel 5 menggunkan uji Spearman hasil signifikansi dari variabel $\mathrm{X}$ atau variabel bebas dengan nilai 0,947 nilai tersebut diatas nilai standart sig. 0,05 maka dapat disumpulkan dalam penelitian ini tidak terdapat heteroskedastisitas.

\section{Pengujian Hipotesis (Uji Parsial T-Test)}

T-Test memiliki tujuan agar diketahui seberapa besar pengaruhnya tiap-tiap independent varible dengan parsial ataupun individu kepada dependent variable. Uji tersebut dihasilkan dari output yang manggunakan software SPSS dengan melihat tabel Cofficients. Hasil untuk pengujian t-test terlihat pada $p$-value (di 
lajur Sig.) dalam setiap variabel independen, apabila nilai $p$-value menghasilkan angka yang lebih kecil dari level of significant yang telah ditetapkan atau t-hitung (di lajur t) lebih tinggi dari pada t-tabel (diperoleh dari two-tailed $\alpha=5 \% \mathrm{df}-\mathrm{k}$ ). Sedangkan kriteria pengujiannya dengan berpatokan pernyataan berikut (Purnomo, 2017):

H0 diterima jika $t_{\text {hitung }}<t_{\text {tabel }}$ dengan $\alpha=5 \%$

Ha diterima jika $t_{\text {hitung }}>t_{\text {tabel }}$ dengan $\alpha=5 \%$

Tabel 6. Hasil Uji T-Test

\begin{tabular}{|c|c|c|c|c|c|c|}
\hline \multirow{2}{*}{\multicolumn{2}{|c|}{ Model }} & \multicolumn{2}{|c|}{ Unstandardized Coefficients } & $\begin{array}{l}\text { Standardized } \\
\text { Coefficients }\end{array}$ & \multirow[b]{2}{*}{$t$} & \multirow[b]{2}{*}{ Sig. } \\
\hline & & $\mathrm{B}$ & Std. Error & Beta & & \\
\hline \multirow[t]{2}{*}{1} & (Constant) & 12.480 & 1.565 & & 7.974 & .000 \\
\hline & LOKASI & .425 & 081 & .497 & 5.249 & .000 \\
\hline
\end{tabular}

Terlihat pada tabel 6, hasil uji T menunjukkan hasil Sig. dengan nilai 0,000. Berdasarkan nilai yang didapatkan, diambil kesimpulan nilai sig. kurang dari $\alpha=$ 5\% maka variabel lokasi memiliki pengaruh terhadap keputusan wisatwan untuk mengunjungi tempat wisata. Artinya bahwa Ha diterima, sebaliknya Ho ditolak.

Berdasarkan penelitian yag telah dilakukan peneliti di Objek Wisata Hutan Pinus Loji Lereng Kelud mendapatkan hasil berdasarkan temuan yang berada di lapangan melalui analisis statistika regresi dengan penyebaran kuisioner kepada responden dengan sampel sebanyak 86. Maka dapat dilihat di pembahasan hasil pengujian pada Uji T yang telah dilakukan peneliti melalui penyebaran kuisioner terhadap 86 responden yang telah diolah oleh peneliti melalui bantuan software statistic yaitu SPSS, maka dapat dilihat pada Tabel 6 bahwa hasil dari Sig. Dengan nilai 0,000. Berdasarkan nilai yang didapat, maka kesimpulanya nilai sig. kurang dari $\alpha=5 \%$ maka variabel lokasi berpengaruh terhadap keputusan berkunjung wisatwan. Artinya bahwa Ha diterima, sebaliknya Ho ditolak.

Pada uraian yang telah dibahas sebelumnya, sehingga bisa dilihat bahwasannya ada pengaruh antara variabel lokasi terhadap keputusan wisatawan mengunjungi Objek Wisata Hutan Pinus Loji Lereng Kelud. Hal ini sesuasi dengan riset yang judulnya "Pengaruh harga, lokasi dan fasilitas terhadap keputusan berkunjung wisatawan di Objek Wisata Dampo Awang Beach Rembang”, dilakukan oleh Anjar Hari Kiswanto yang mana Lokasi merupakan salah satu variabel independen yang mempengaruhi Keputusan berkunjung. 


\section{KESIMPULAN DAN SARAN}

Dalam penelitian ini peneliti memiiki tujuan agar diketahui ada tidaknya pengaruh lokasi terhadap keputusan berkunjung seorang wisatawan. Dari hasil penelitian dapat disimpulkan bahwa lokasi mempunyai pengaruh terhadap minat kunjung wisatawan di Objek Wisata Hutan Pinus Loji Lereng Kelud secara siginifikan. Hal tersebut terlihat dari uji $\mathrm{T}$ yang memberikan nilai Sig. sebesar 0,000 kurang dari $\alpha=5 \%$.

Saran yang dapat diberikan pada penelitian ini bagi pihak pengelola Objek Wisata Hutan Pinus Loji Lereng Kelud adalah pihak pengelola harus benar-benar memertahankan keadan ligkungan agar terjaga keindahan dan kebersihan di Objek Wisata Hutan Pinus Lijo Lereng Kelud. Serta dalam hal ini pihak pengelola juga harus melihat dari faktor lain seperti kurangnya petunjuk jalan untuk menuju objek wisata tersebut, menata tempat parkir yang tersedia dan memberikan konsep yang lebih lagi di Objek Wisata Hutan Pinus Loji Lereng Kelud agar terlihat lebih bagus lagi dan dapat meningkatkan wisatwan yang berkunjung di Objek Wisata Hutan Pinus Loji Lereng Kelud. Untuk penelitian selanjutnya agar dapat dikembangkan sehingga dapat menjadi penelitian yang lebih baik lagi dengan cara atau variasi metode lain.

\section{DAFTAR PUSTAKA}

Arikunto, Suharsimi. 2006. Metode Penelitian Kualitatif. Jakarta: Bumi Aksara. Ghozali, Imam. (2006). Aplikasi Analisis Multivariate dengan Program SPSS. Semarang: Badan Penerbit Universitas Diponegoro.

Kotler, Philip. (2005). Menejemen Pemasaran. Jilid I dan II. Jakarta: PT Indeks. Manullang, M. (1990). Dasar-Dasar Menejemen. Jakarta: Galia Indonesia. Nugroho, Agung. (2005). Strategi Jitu Memilih Metode Statistic Penelitian dengan SPSS. Yogyakarta: Andi.

Purnomo, Rochmat Aldy. (2017). Analisis Statistik Ekonomi dan Bisnis dengan SPSS. Ponorogo: CV. Wade Group bekerjasama dengan UNMUH Ponorogo Press.

Siregar, Syofian. (2017). Metode Penelitian Kuantitatif Cetakan ke-4. Jakarta: Kencana.

Sugiyono. (2017). Metode Penelitian Kuantitatif, Kualitatif, dan R\&D. Bandung: Alfabeta.

Tjiptono, Fandy. 2005. Pemasaran Jasa. Malang: Banyumedia Publishing.

Zulfikar dan Budiantara, I. Nyoman. (2014). Manajemen Riset dengan Pendekatan Komputasi Statistika. Yogyakarta: Deepublish. 